\title{
Plant Growth Promoting and Antagonistic Activity of Rhizospheric Strains Isolated from Wilt Affected Rhizosphere of Lentil (Lens culinaris Medik.) Crop against Wilt Pathogen Fusarium oxysporum f.sp.lentis
}

\author{
Shalini Srivastava $^{1 *}$, Adesh kumar ${ }^{1}$, Kusum Sharma ${ }^{2}$, Praveen Tiwari ${ }^{1}$, \\ Minakshi Tiwari ${ }^{1}$, Kirti Srivastava ${ }^{3}$ and Alok Srivastava ${ }^{3}$
}

${ }^{1}$ Department of Plant Molecular Biology \& Genetic Engineering, Acharya Narendra Deva University of Agriculture \& Technology, Kumarganj, Ayodhya -224229 (UP) India

${ }^{2}$ ICAR-Indian Institute of Pulses Research, Kalyanpur, Kanpur, 208024 (U.P), India

${ }^{3}$ National Bureau of Agriculturally Important Microorganisms Mau Nath Bhanjan -275103 (UP) India

*Corresponding author

\section{Keywords}

Bio-agents,

Pathogen, Lentil crop, Wilt disease, Antagonism

\section{Article Info}

Accepted: 04 September 2020 Available Online: 10 October 2020

\section{A B S T R A C T}

Fusarium wilt is a soil-borne disease, which negatively affects the lentil crop widespread in India and affecting the lentil crop productivity. So the present study was conducted to evaluate the efficacy of bioagents against wilt pathogen Fusarium oxysporum f.sp.lentis of lentil crop through antagonistic activity. Rhizospheric strains were isolated from wilt affected lentil plant in different regions of Eastern UP like Faizabad, Mau, Varanasi, Ghazipur. A total of 20 bacterial strains were isolated and tested for antagonistic activity by co-culture method against pathogen (Fusarium oxysporum sp.lentis), out of which 8 strains (B1, B2, B3, B4, B5, B6, B7, B8) showed antagonistic activity against Fusarium oxysporum f.sp.lentis. Further study identified that all the 8 strains also showed PGPR activity such as phosphate solubilization, Zn solubilisation, siderophore production, HCN production and IAA production. Out of these 8 bacterial strains, three strains B4, B5 and B8 were found to be more effective against the same pathogen on the basis of mycillium growth as compare to B1,B2,B3,B6,B7 strains as well as shows greater PGPR activities such as $\mathrm{PO}_{4}{ }^{+}$and $\mathrm{Zn}^{+}$solubilzation ranges from 3 strain minimum to maximum $\mathrm{B} 7, \mathrm{~B} 1$ and B8 $28 \%, 40 \%$ and $60 \%$ as compare to B4, B6, B5, B3, B2 8.33\%, 8.33.\%, 20, 20, $28 \%$ and B5, B8 and B7 6.6\%,4\%, 4\% B3, B4, B2, B1, 2.66\%, 0.5\%, 2.5, 2.66, strain minimum to maximum and siderophore, only 3 strains B1, B8 and B5, 20\%, 33\% and $50 \%$. On the basis of qualitative analysis, NH3 production was maximum B1, (+++), B5 $(+++), \mathrm{B} 8(++)$ as compare to B2 (+), B3 (+), B4 (++), B6 (++), B7 (++). HCN B8 (+++), B5 $(+++)$, B1 (++) and IAA production B4 (++), B5 (+++), B8 (++) as compare to 5 strain B1 (+), B2 (+), B3 (++), B6 (+), B7 (+) respectively. Study concluded that these strains characterized as bio-control agents along with beneficial PGPR activities and are found to have more efficient activity to suppress the wilt pathogen fusarium oxsporum $f$. sp. lentis in lentil that would further used for plant growth promotion of lentil crop. 


\section{Introduction}

Lentil (Lens culinaris Medik.) is a member of Leguminaceae family and commonly known as legume, massoor or poor man's meat. Lens is consists of cultivated L. culinaris and six related wild taxa (Sauer et al., 2017).The global production of lentil has reached nearly 5.0 million tonnes in 2014 (Ahmad Nasim 2018).It is the second largest growing rabi pulse after chickpea in India. Lentils (Lens culinaris Medikus) produces commonly in cold weather which is an important pulse crop grown widely throughout the Indian subcontinent, Canada, Turkey, Australia, USA, Nepal, China and Ethiopia. About 80 percent of the lentil production in India during 2015-16 has been reported from Madhya Pradesh (30.94\%), Uttar Pradesh (28.72\%), Bihar (15.24\%) and West Bengal (5.81\%) (Ahmad et al., 2018).Lentil has a high nutritional value and major source of dietary proteins $(25 \%)$ after soyabeans in humans and animal diet (Rahman et al., 2010) and also plays a significant role in the improvement of soil fertility (Frederick et al., 2006). Its cultivation enriches soil nutrients status by adding nitrogen, carbon and organic matter which promotes sustainable cereal based systems of crop production (Sarker and Kumar, 2011). Fusarium wilt disease caused by pathogen Fusarium oxysporum f.sp. lentis is the most important biological constraints to productivity of lentil worldwide (Bhalla et al., 1992) and is considered as to be the most important biotic stress affecting the crop's productivity (Khare, 1981). It is a soil borne root pathogen, colonizing the xylem vessels and blocking them completely and in this way it prevents water to reach towards the other parts of the crop. Wilt symptoms appear from flowering to late pod-filling stage and are characterized by sudden drooping of top leaflets of the affected plant, leaflet closure without premature shedding, dull green foliage followed by wilting of the whole plant or individual branches. Seeds from plants affected in mid-pod-fill to late pod-fill are often shriveled (Garkoti et al, 2013; Izquierdo and Morse, 1975; Bayaa et al., 1986; Agrawal et al., 1993).

Lentils legumes have symbiotic association with rhizobium which helps to fixed the atmospheric nitrogen and maintain soil fertility. Many environmental stress factors such as drought which negatively affect the establishment of the symbiotic relationship through low humidity and high soil temperature and causes damage to the plants as well as to reduce the percentage of survival of the bacteria (Nascimento et al., 2012). Several studies show that how biotic and abiotic stresses can adversely affect nodulation (Athar, 1998; Howieson and Ballard, 2004; Nascimento et al., 2012). Abiotic stresses such as drought and salinity can be largely overcome by selecting rhizobia strains with tolerance to these adverse environmental conditions (Athar 1998; Zahran 1999). In the same way, the coinoculation of rhizobia with rhizospheric bacteria can promote root growth and yield. This is an alternative to increase abiotic stress and biotic stress tolerance in legumes (Rashid et al., 2012; Sarma and Saikia, 2011).

Plant growth-promoting rhizobacteria (PGPR) promotes growth through various mechanisms such as phosphate solubilization, nitrogen fixation and phytohormone production (Rashid et al., 2012). Some beneficial bacteria has found to have the ability of synthesize the hormone indole acetic acid (IAA) which controls the growth and development of the plant and acting as a signal molecule to control the expression of several genes (Duca et al., 2014). Hence keeping in view of beneficial effect of PGPR on fusarium wilt disease potential, the rhizospheric strains were isolated from wilt affected lentil crop of agro-climatic zone of eastern UP such as 
Faizabad, Mau, Varanasi, Gazipur. Sandy alluvial, clayey and sodic soils are the major type of soils in these zones. The zone receives $1000-1200 \mathrm{~mm}$ average rainfall whereas temperature varies from $42^{\circ} \mathrm{c}$ to $46^{\circ} \mathrm{c}$.

The inoculation of legumes with effective rhizobia is a recommended agronomic practice that can increase yields. However, under stressful environments selected inoculants are less competitive than soil naturalized rhizobia populations and hence considerably reduces the nodule occupation by the selected strain (Mishra et al., 2011; Gerding et al., 2014). In this situation, coinoculation of rhizobia with PGPR allowed higher rates of nodulation, increased rhizobia survival and higher number of the inoculants in the nodules which lead to an increase in nitrogen fixation effectiveness (Glick et al., 2007; Fox et al., 2011; Nascimento et al., 2012; Sarma and Saikia, 2014). So it might be possible to develop induction of systemic resistance in lentil crop against biotic stress of wilt (Fusarium oxysporum f.sp.lentis) disease. The objectives of this research were to select lentil rhizospheric bacteria based on antagonistic activity and PGPR production and then to evaluate their effects against wilt pathogen (Fusarium oxysporum f.sp.lentis).

\section{Materials and Methods}

\section{Plant Pathogens}

Phytopathogenic fungal strain Fusarium oxysprom $f$. sp.lentis used in this study were obtained from the Indian Institute of Pulse Research, Kanpur, India and were subcultured and maintained on PDA medium at $4^{0} \mathrm{C}$.

\section{Isolation of rhizospheric strains}

The soil samples were collected from naturally infected lentil plants showing characteristic symptoms of fusarium wilt from
Experimental farm, N.D. University of Agriculture and Technology, Kumarganj, Faizabad, Mau and Varanasi, Mirzapur, Ghazipur during kharif season 2016-17. Rhizospheric soil samples (10 g) were transferred to $90 \mathrm{ml}$ sterile distilled water and mixed thoroughly by shaking the flask on a rotatory shaker for $5 \mathrm{~min}$. After serial dilution $0.1 \mathrm{ml}$ suspension was spread over presterilized and cooled down nutrient agar plates in triplicates. Inoculated plates were incubated at $31^{\circ} \mathrm{C}$ for $24-48 \mathrm{~h}$. Rough and abundant colonies with waxy growth (1-4 mm diameter) and irregular spreading edge were obtained. On the basis of preliminary investigation, 20 isolates (B1-B20) were selected and maintained on the NAM (Nutrient Agar Medium) slants at $4^{0} \mathrm{C}$ for further use. Physiological and biochemical characterization of isolates were performed by using the method of Chung et al., 2011.

\section{Antagonistic activities against pathogenic fungus}

All the isolates of rhizospheric strains were tested for their antifungal activities against $F$. oxysporum $f$. sp. lentis on agar medium containing 1:1 ratio of PDA and NAM. Rhizospheric isolates were inoculated on the surface of agar plate $2 \mathrm{~cm}$ away from fungal disc. Antagonist activity was observed after incubation at $28 \pm 1^{\circ} \mathrm{C}$ up to 7 days.

\section{Preliminary screening and characterization of biocontrol agents}

Twenty bacteria were isolated from the rhizosphere and root of lentil showing substantial inhibition zones against Fusarium oxysporum $f$. sp. lentis in vitro. Out of twenty, eight isolates $(40 \%)$ of bacterial strains showing high antifungal activity against pathogen were selected and used in the subsequent in vitro inhibition tests. 


\section{Phosphate solubilization}

Phosphate solubilization ability of isolated strains was detected by spotting them separately on Pikovskaya's agar plates (Pikovskaya, 1948) by Phosphate Solubilization-Bromophenol Blue medium (NBRIP) from National Botanical Research Institute along with bromophenol blue as $\mathrm{pH}$ indicator.

Then these plates were incubated at $28 \pm 1^{0} \mathrm{C}$ for 3 days and observed for appearance of clearing zone around the colonies due to the solubilization of inorganic phosphate by bacteria. Quantitative estimation of water extractable free inorganic $\mathrm{P}(\mathrm{Pi})$ was carried out as described by Dubey and Maheshwari (2012).

\section{Zinc solubilization}

Zinc solubilization ability of the isolates was detected by spotting the log phase culture of bacterial strains on tris-minimal medium plates having zinc phosphate and zinc carbonate as a source of insoluble inorganic zinc along with bromophenol blue as $\mathrm{pH}$ indicator.

The inoculated plates were then incubated at $28 \pm 1^{\circ} \mathrm{C}$ for 3 days and observed for the clearing zone around the colonies (due to the solubilization of inorganic zinc by bacteria) (Kamran et al., 2017).

Table.1 Qualitative analysis of PGPR activity of rhizospheric strain

\begin{tabular}{|c|c|c|c|c|c|c|}
\hline Isolates & $\begin{array}{c}\text { Phosphate } \\
\text { solubilization }\end{array}$ & $\begin{array}{c}\text { Zinc } \\
\text { solubilization }\end{array}$ & $\begin{array}{c}\text { Siderophore } \\
\text { solubilization }\end{array}$ & $\begin{array}{c}\text { Ammonia } \\
\text { Production }\end{array}$ & $\begin{array}{c}\text { IAA } \\
\text { production }\end{array}$ & $\begin{array}{c}\text { HCN } \\
\text { production }\end{array}$ \\
\hline B1 & +++ & ++ & ++ & ++ & + & ++ \\
\hline B2 & ++ & ++ & + & + & + & Negative \\
\hline B3 & ++ & ++ & Negative & + & + & Negative \\
\hline B4 & ++ & ++ & Negative & + & ++ & + \\
\hline B5 & ++ & ++++ & ++ & ++ & ++ & +++ \\
\hline B6 & ++ & + & Negative & + & + & + \\
\hline B7 & ++++ & +++ & Negative & + & + & + \\
\hline B8 & ++ & +++ & +++ & ++ & ++ & +++ \\
\hline
\end{tabular}

Table.2 Quantitative analysis of Phosphate solubilization of rhizospheric strain from lentil crop

\begin{tabular}{|c|c|c|c|}
\hline Strain no. & $\begin{array}{c}\text { Bacterial growth zone } \\
(\mathbf{m m})\end{array}$ & $\begin{array}{c}\text { Halo zone } \\
(\mathbf{m m})\end{array}$ & Efficiency (\%) \\
\hline $\mathbf{B}_{\mathbf{1}}$ & 10 & 14 & 40 \\
\hline $\mathbf{B}_{\mathbf{2}}$ & 14 & 10 & 28 \\
\hline $\mathbf{B}_{\mathbf{3}}$ & 10 & 12 & 20 \\
\hline $\mathbf{B}_{\mathbf{4}}$ & 13 & 12 & 8.33 \\
\hline $\mathbf{B}_{\mathbf{5}}$ & 10 & 12 & 20 \\
\hline $\mathbf{B}_{\mathbf{6}}$ & 13 & 12 & 8.33 \\
\hline $\mathbf{B}_{\mathbf{7}}$ & 14 & 10 & 28 \\
\hline $\mathbf{B}_{\mathbf{8}}$ & 10 & 16 & 60 \\
\hline
\end{tabular}


Table.3 Quantitative analysis of Zn solubilization of rhizospheric strain from lentil crop

\begin{tabular}{|c|c|c|c|}
\hline Strain no. & $\begin{array}{c}\text { Bacterial growth zone } \\
(\mathbf{m m})\end{array}$ & $\begin{array}{c}\text { Halo zone } \\
(\mathbf{m m})\end{array}$ & Efficiency (\%) \\
\hline $\mathbf{B}_{\mathbf{1}}$ & 3 & 8 & 2.66 \\
\hline $\mathbf{B}_{\mathbf{2}}$ & 4 & 10 & 2.5 \\
\hline $\mathbf{B}_{\mathbf{3}}$ & 6 & 10 & 1.66 \\
\hline $\mathbf{B}_{\mathbf{4}}$ & 4 & 8 & 0.5 \\
\hline $\mathbf{B}_{\mathbf{5}}$ & 3 & 20 & 6.6 \\
\hline $\mathbf{B}_{\mathbf{6}}$ & 4 & 10 & 2.5 \\
\hline $\mathbf{B}_{\mathbf{7}}$ & 2 & 8 & 4 \\
\hline $\mathbf{B}_{\mathbf{8}}$ & 3 & 12 & 4 \\
\hline
\end{tabular}

Table.4 Quantitative analysis of Siderophore solubilization of rhizospheric strain from lentil crop

\begin{tabular}{|c|c|c|c|}
\hline Strain no. & $\begin{array}{c}\text { Bacterial growth zone } \\
(\mathbf{m m})\end{array}$ & $\begin{array}{c}\text { Halo zone } \\
(\mathbf{m m})\end{array}$ & Efficiency (\%) \\
\hline $\mathbf{B}_{\mathbf{1}}$ & 5 & 4 & 20 \\
\hline $\mathbf{B}_{\mathbf{2}}$ & - & - & Negative \\
\hline $\mathbf{B}_{\mathbf{3}}$ & - & - & - Negative \\
\hline $\mathbf{B}_{\mathbf{4}}$ & - & - & - Negative \\
\hline $\mathbf{B}_{\mathbf{5}}$ & 4 & 12 & 50 \\
\hline $\mathbf{B}_{\mathbf{6}}$ & - & - & - Negative \\
\hline $\mathbf{B}_{\mathbf{7}}$ & - & - & Negative - \\
\hline $\mathbf{B}_{\mathbf{8}}$ & 6 & 8 & 33 \\
\hline & & & Negative \\
\hline
\end{tabular}

Fig.1 Rhizobial strains showing antagonistic activity against pathogen on PDA media by dual- culture assay
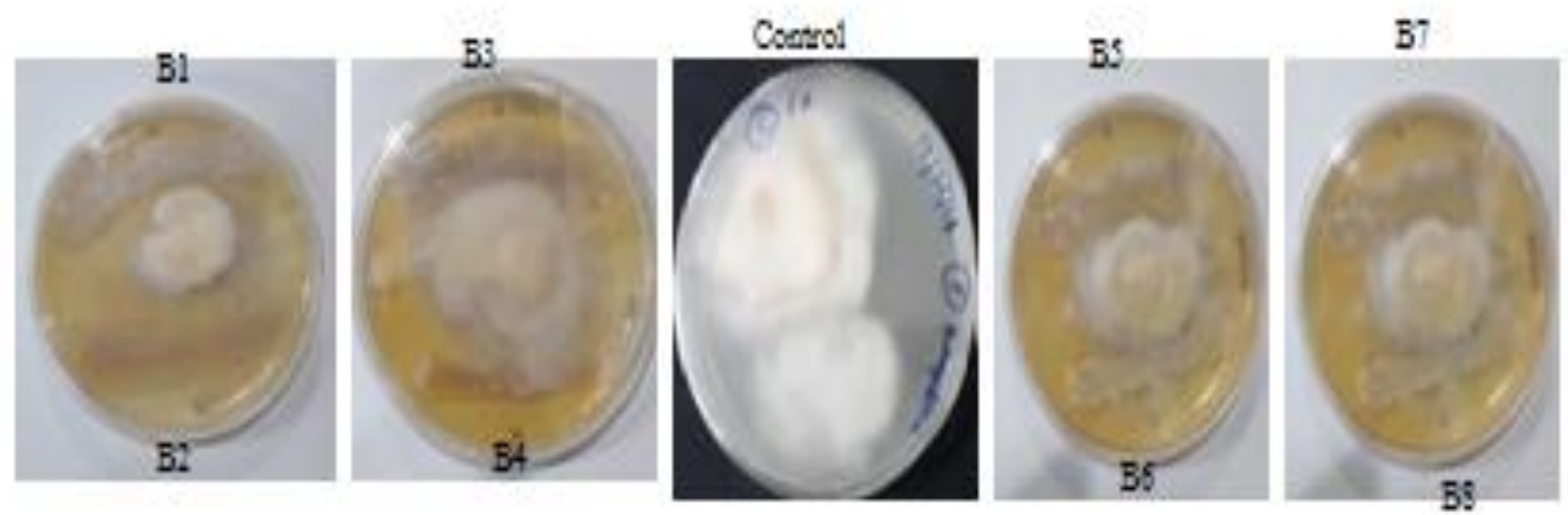
Fig.2 Rhizospheric bacterial strains showing production of phosphate solubilization
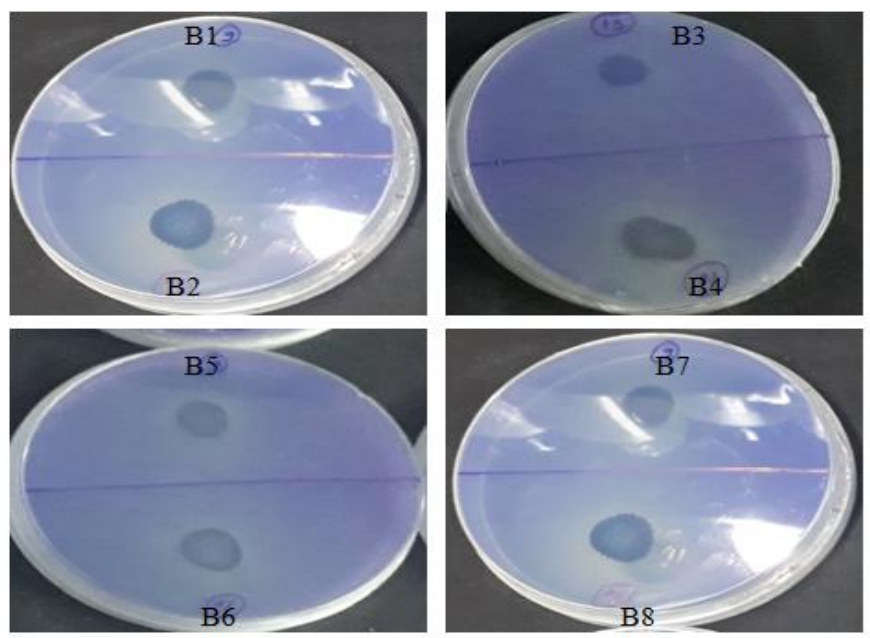

Fig.4 Rhizospheric bacterial strains showing production of zinc solubilization
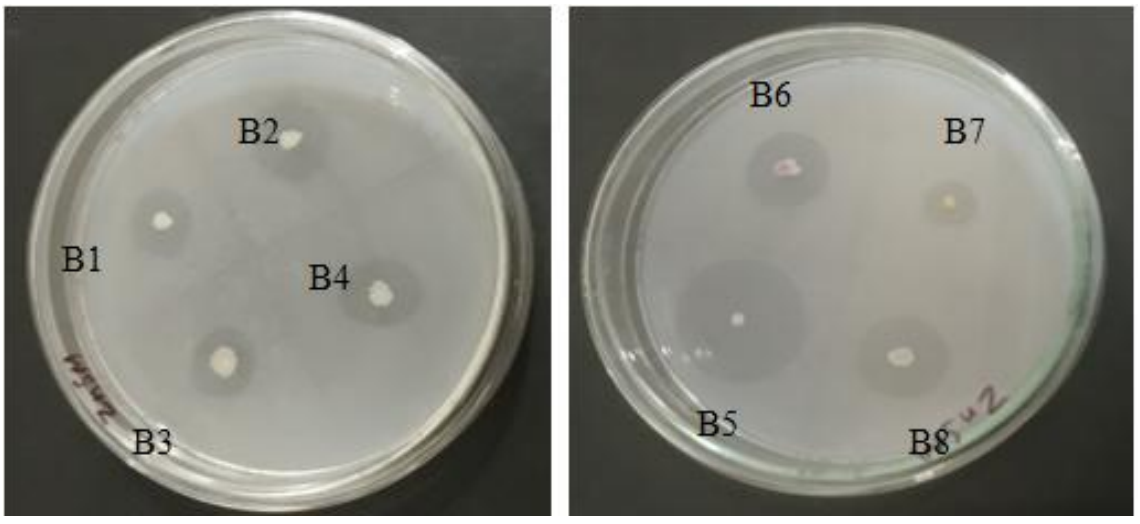

Fig.4 Rhizospheric bacterial strains showing siderophore production in specific strains denoted by arrow
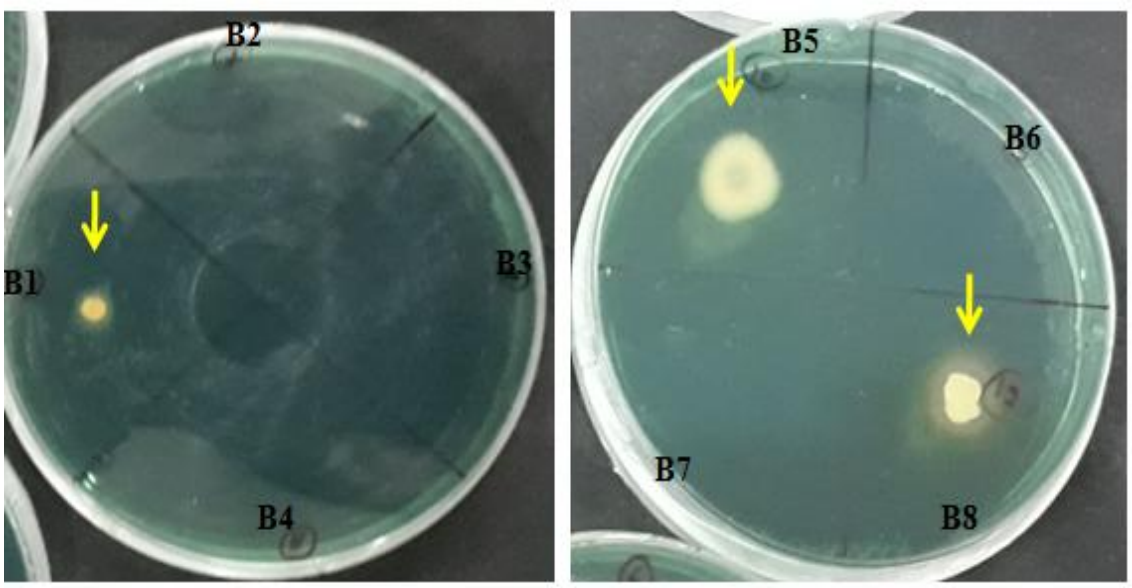
Fig.5 Rhizospheric bacterial strains showing ammonia production

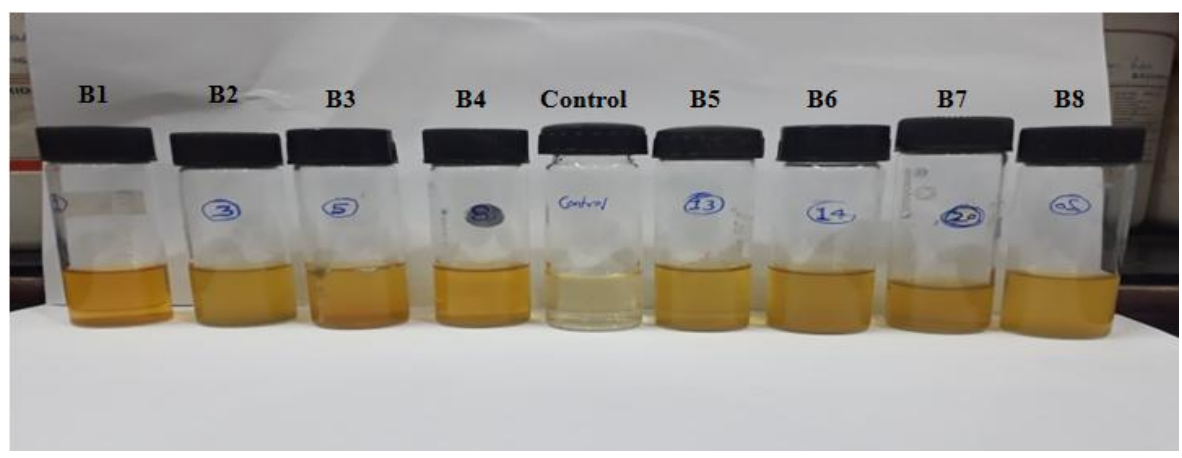

Fig.6 Rhizospheric bacterial strains showing IAA production

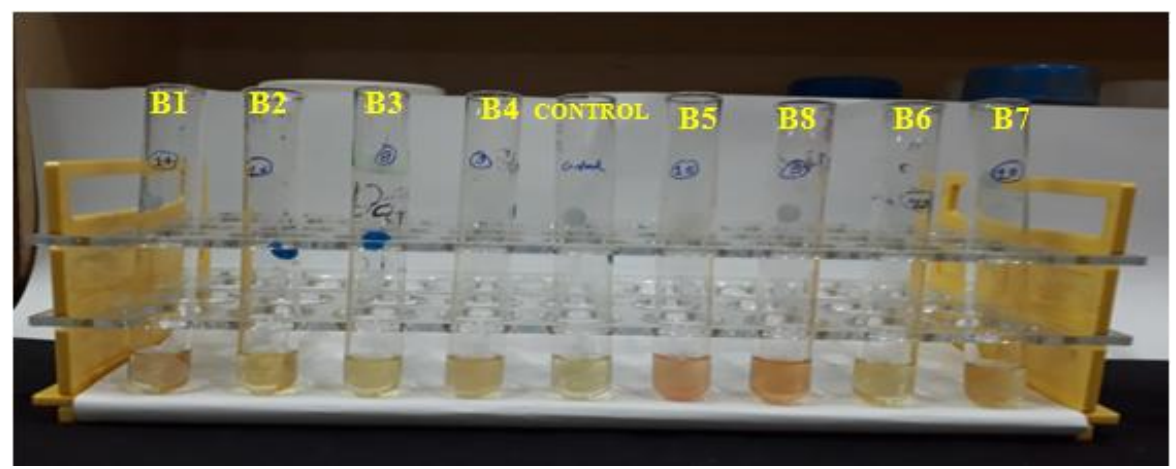

Fig.7 Rhizospheric bacterial strains showing HCN production

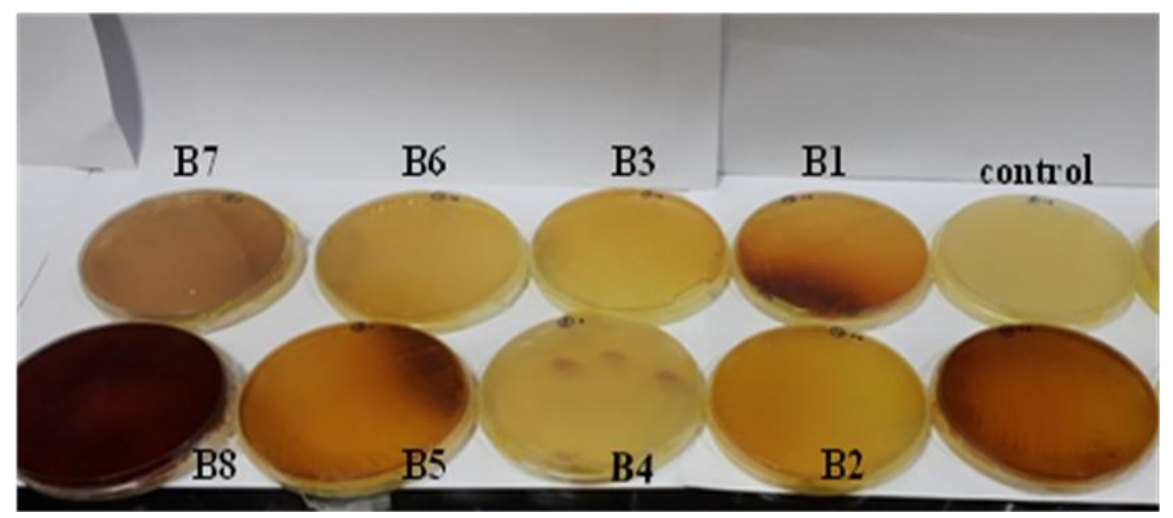

\section{Siderophore production}

Siderophore production was determined on Chrome Azurol S (CAS) medium following the method of Schwyn and Neilands (1987). The bacterial strains ( $24 \mathrm{~h}$ old cultures) were spotted separately on CAS medium and incubated at $28 \pm 1^{0} \mathrm{C}$ for $48-72 \mathrm{~h}$. Formation of orange to yellow halo around the colonies confirmed the production of siderophore.

\section{Ammonia production}

For the test of production of ammonia, each identified rhizobacterial strain was grown in peptone broth $(10 \mathrm{ml})$ and incubated at $25^{\circ} \mathrm{C}$ 
for $48-72 \mathrm{~h}$. After incubation, $0.5 \mathrm{ml}$ of Kessler's reagent was added to bacterial suspension. The development of brown to yellow colour indicated ammonia production. Cappuccino J.C Sherman (1992).

\section{Indole-3-acetic acid (IAA) production}

IAA production by bacterial isolates was determined by following the Gordon and Weber method (1951). The bacterial isolates were grown on Luria Bertani (LB) broth and incubated at $28^{\circ} \mathrm{C}$ for $24 \mathrm{~h}$ at $120 \mathrm{rpm}$. Exponentially grown culture (108 cells $\mathrm{ml}-1)$ was centrifuged at $10,000 \mathrm{rpm}$ for $15 \mathrm{~min}$ at $4^{0} \mathrm{C}$ to collect supernatant. Two drops of Ophosphoric acid was added to $2 \mathrm{ml}$ of supernatant, appearance of pink colour confirmed the production of IAA.

\section{HCN determination}

$\mathrm{HCN}$ production was determined by modified method of Bakker and Schippers (1987). Exponentially grown cultures (8-10 cells/ml) of strains were streaked on solid agar plates supplemented with or without $4.4 \mathrm{~g}$ glycine 1 -1 with simultaneous addition of filter paper soaked in $0.5 \%$ picric acid in $1 \% \mathrm{Na}_{2} \mathrm{CO}_{3}$ in the upper lids of plates along with uninoculated control. The plates were sealed with parafilm and incubated at $28 \pm 1^{\circ} \mathrm{C}$. Development of colour from yellow to light brown, moderate brown or strong brown was examined for putative $\mathrm{HCN}$ production.

\section{Results and Discussion}

\section{Morphological description of freshly isolated microbial bioagents}

On the basis of gram's staining and morphological identification, out of 8 bacterial isolates only 2 isolates B5 and B8 were characterized as gram-positive, rod shaped, endospore former with white, dry and fold, opaque and irregular edged colonies on NAM plates. Similar result was observed in our strains that morphological, of all eight isolates showed as gram-positive, rod shaped, endospore former with white, dry and fold, opaque and irregular edged colonies on NAM plates Kumar Pankaj et al., (2012). In our experiments gram stained bacteria shows the purple colour which admit that the strains are gram positive. According to Hans Christian's (1884), Gram staining method, Gram-positive bacteria appear to be purple-coloured under optical microscope by absorbing the crystal violate stain used in the said test. This is because of the thick peptidoglycon layer in the bacterial cell wall which retains the stain while washed away from the rest of the sample in the decolorization stage of the test Sizar; Omeed (2020).

\section{Antagonistic activities of isolates by Co- culture method}

All the strains were screened for antagonistic activity. Out of 20 only 8 bacterial isolates B1, B2, B3, B4, B5, B6, B7 and B8 showed antagonistic activity against the pathogen F.oxysporum f.spp.lentis (Fig. 1). The maximum inhibition (\%) in radial growth of F.oxysporum f.spp.lentis was recorded by the strains B4, B5 and B8 on the basis of mycillium growth as compare to control where only pathogen was inoculated in the absence of bacterial strains (Fig. 1) through dual culture method. Increase in fungal inhibition corresponded with incubation period. Alteration in structural architect and lysis of mycelia led to morphological deformities that finally resulted in fungal death. Fungal inhibition was more pronounced in dual culture as compared to that of cell-free culture filtrates (Fig. 1). Similar findings recorded by Kaur et al., (2007), reported that 14 out of 96 Pseudomonas isolates from chickpea rhizosphere were highly antagonistic to 
F.oxysporum spp. Growth inhibition of F.oxysporum may be due to fungi static effect or might be attributed to the secretion of antibiotics by the fungi or other inhibitory substances produced by the antagonistis.

\section{Phosphate solubilization}

All the selected 8 antagonistic bacterial strains were found to form a clear halozone around their spot inoculation. Pikovskaya's medium having bromothymol blue (BTB), changed its colour from blue to yellow due to decrease in $\mathrm{pH}$ of growth medium. Strains B1 and B8 showed maximum phosphate solubilization efficiency ranges from $60 \%$ to $40 \%$ as compare to others like B4, B6, B3, B5 and $\mathrm{B} 2$ as $8.33 \%, 8.33 \%, 20 \%, 20 \%, 28 \%$. In our study BPR7 was found as the best solubilizer range of inorganic phosphates due to the production of organic acid, similar to the findings was reported by the previous researches Singh et al., (2008) and Sanjotha et al., (2011).BPR7 was also found to solubilize calcium phytate and sodium phytate (organic P). Mineralization of these compounds is carried out by several important enzymes such as phosphatases (also called phosphohydrolases). PGPR belonging to Bacillus, Burkholderia, Enterobacter, Pseudomonas, and Staphylococcus are the most common-phytate producer (Hussin et al., 2007) (Fig. 2).

\section{Zinc solubilization}

The isolates showed zinc solublization activity by changes in $\mathrm{pH}$ as indicated by change in colour by forming a clear halozones around bacterial spot on the medium. Four bacterial strains B1, B2, B3, B4, B6, B7 and $\mathrm{B} 8$ shows $\mathrm{Zn}$ solubilization ranges (2.66\%), (2.5\%), (1.66\%), (0.5\%), (2.5\%), $(4 \%)$ and $(4 \%)$ respectively. Maximum solublization found in B5 (6.6) Fig. 3 and Table 3. Similar findings were reported by
Kumar P. et al., (2012) who showed BPR7 bacterial strain was found able to $\mathrm{Zn}$ solubilization. Bacterial strains with PGP activity along with zinc and phosphate solubilizing activity was reported by bacteria Iqbal et al., (2010).

\section{Siderophore production}

Three bacterial strains B5, B8, B1 were found to produced siderophore as indicated by formation of orange halos around their spots on the CAS agar medium. Bacterial strains B5 shows maximum $(50 \%)$ siedrophore production efficiency (Fig. 4 and Table 1 and $2)$. It was reported that the bacterial strain BPR7 was found to have plant growth promoting and antagonistic properties against various phytopathogens (Singh et al., 2008).

\section{Ammonia production}

Out of 8 antagonistic isolates on the basis of qualitative analysis, bacterial strains $\mathrm{B} 1(++)$, B2 (++), B3 (++), B4 (++), B6 (++) and B7 $(+)$ were found to have the ammonium production activity (Table 1 and Fig. 5). Bacterial strains $\mathrm{B} 1(++), \mathrm{B} 5(+++)$ and B8 $(++)$ were found to have maximum ammonia production as compare to others (Table 1). The development of brown to yellow colour indicated ammonia production. Cappuccino J.C Sherman (1992). Similar ammonium production activity was observed in strain serretia (Agbodjato Nadege A. et al., 2015).

\section{Indole-3-acetic acid (IAA) production}

Out of 8 bacterial isolates (B1), (B2), (B3), (B4), (B5), (B6), (B7) and (B8) were showed IAA production. Development of pink colour with addition of tryptophan in culture LB broth was also observed into their cell-free supernatant. Maximum IAA production was recorded in strain $\mathrm{B} 4(++), \mathrm{B} 8(++)$ and B5 $(+++)$ broth culture (Table 1 and Fig. 6). In- 
vitro IAA production by Bacillus spp. in significant amount has also been reported by Singh et al., (2008) and Mehta et al., (2010). Production of IAA without tryptophan by all BPR isolates is similar to above finding.

\section{HCN determination}

Our data suggested that all the rhizobacteria strains were able to produce hydrogen cyanide which was categorized as low, medium and high on the basis of light yellow to brown colour development. On the basis of qualitative analysis out of 8 only 3 strain B8 $(+++), \mathrm{B} 5(+++)$ and $\mathrm{B} 1(++)$ were found to have maximum $\mathrm{HCN}$ production as compare to bacterial strains B4 (++), B6 (++) and B7 $(++)$ (Table 1 and Fig. 7). In the presence of glycine and $\mathrm{FeCl} 3$, the deep brown colour of filter paper was observed, giving a clear indication of $\mathrm{HCN}$ production by bacterial strains. Similar findings recorded by kaur et al., (2007), reported that 14 out of 96 Psudomonas isolates from chickpea rhizosphere were highly antagonistic to F.oxysporum sp. Growth inhibition of F.oxysporum may be due to fungistatic effect or might be attributed to the secretion of antibiotics by the fungi or other inhibitory substances produced by the antagonistis.

\section{Acknowledgements}

Authors are very thankful to Dr. Adesh Kumar from Narendra Dev University Kumarganj, Ayodhya for his support and guidance. Authors are also thankful to Dr. Alok Srivastava from NBAIM, Mau to provide lab facilities and his valuable suggestions.

\section{References}

Ashutosh Sarkar and shiv kumar (2011) Lentils in production and food systems in west Asia and Africa.
Bakker A.W., Schippers B. (1987), Microbial cyanides production in the rhizosphere in relation to potato yield reduction and Pseudomonas spp. mediated plant growth stimulation. Soil Microbiol Biochem 1987; 19: 451-7.

Bakker, A.W. and Schipper, B. (1987), Microbial cyanide production in the rhizosphere in relation to potato yield reduction and Pseudomonas spp. mediated plant growth stimulation. Soil Biol. Biochem., 19: 451457.

Bayaa B, Erskine W, Hamdi A(1995) Evaluation of a wild lentil collection for resistance to vascular wilt. Genetic Resources and Crop Evolution.; 42: 231-235.

Bhalla M.K., C. Nozzolillo and E. Schneider (1992), Observation on the responses of lentil root cells to hypha of Fusarium oxysporum. J. Phytopathol., 135, 335-341

By Neha Tiwari, Seid Ahmed, Shiv Kumar and Ashutosh Sarker (2018) Fusarium Wilt: A Killer Disease of Lentil Submitted: June 5th 2017Reviewed: November 15th 2017Published: February 21st DOI: 10.5772/intechopen.72508.

Cappuccino J.C, sherman N (1992) In Microbiology. A Laboratory Manual, New York, PP. 125 -79 Academic distribution New Delhi.

Dubey RC, Maheswari D K. Practical microbiology. New Delhi: S. Chandand C0: 2011.

Freidrick et al., (2006), Application of biotechnology in breeding lentil for resistance to biotic and abiotic stress Euphytica, 147: 149-165

Garkoti A, Kumar V, Tripathi HS, (2013), Control of wilt disease of lentil through bio control agents and organic amendments in Tarai region of Uttarakhand, India. Journal of Environmental Biology.; 35(6):1067- 
1070.

Hussin ASM, Farouk AE, Greiner R, Salleh HM, Ismail AF. (2007), Phytate degrading enzyme production by bacteria isolated from Malaysian soil. World J Microbiol Biotechnol 23:1653-60.

Iqbal U, Jamil N, Ali I, Hasnain S. (2010) Effect of zinc-phosphate-solubilizing bacterial isolates on growth of Vigna radiata. Ann Microbiol; 60:243-8.

kaur R, Singh RS, Alabouvetic C (2007). Antgonistic activity of selected isolates of fluorescent Pseudomonas against Fusarium oxysporum f.sp. ciceris. Asian J. Pl. Sci. 6:4446-456.

Khare, M. N. 1981. Farnham Royal, UK Commonwealth Agricultural Bureaux. Aleppo, Syria:, ICARDA. In: Lentils, pp. 163-172 (eds. C. Webb and G. Hawtin.

Mehta P, Chauhan A, Mahajan R, Mahajan PK, Shirko CK. (2010). Strain of Bacillus circulans isolated from apple rhizosphere showing plant growth promoting potential. Curr Sci; 98(4): 538-42.

Pikovskaya RI. (1948), Mobilization of phosphorus and soil in connection with the vital activity of some microbial species. Mikrobiologii; 17: 362-70.

S.A. Gordon and R.P. Weber (1951), Colorimetric estimation of indoleacetic acid. Plant Physiology. 26: 192195.

Sanjotha P, Mahantesh P, Patil CS.(2011) Isolation and screening of efficiency of phosphate solubilizing microbes. Int $\mathbf{J}$ Microbiol Res; 3 (1): 56-8.

Sauer, Jonathan D. (2017). Historical Geography of Crop Plants: A Select Roster. Routledge.

Schwyn B, Neilands J (1987), Universal chemical assay for the detection and determination of siderophores. Anal Biochem., 160: 47-56.

Schwyn B, Neilands JB (1987), Universal chemical assay for the detection and determination of siderophores. Analytical Bioche.160:47-56. doi: 10.1016/0003-2697(87) 190612-9.

Singh N, Pandey P, Dubey RC, Maheshwari DK (2008).Biological control of root rot fungus Macrophomina phaseolina and growth enhancement of Pinus roxburghii (Sarg.) by rhizosphere competent Bacillus subtilis BN1. World J Microbiol Biotechnol; 24:1669-79.

\section{How to cite this article:}

Shalini Srivastava, Adesh kumar, Kusum Sharma, Praveen Tiwari, Minakshi Tiwari, Kirti Srivastava and Alok Srivastava. 2020. Plant Growth Promoting and Antagonistic Activity of Rhizospheric Strains Isolated from Wilt Affected Rhizosphere of Lentil (Lens culinaris Medik.) Crop against Wilt Pathogen Fusarium oxysporum f.sp.lentis. Int.J.Curr.Microbiol.App.Sci. 9(10): 117-127. doi: https://doi.org/10.20546/ijcmas.2020.910.016 